\title{
PROSELITISMO RELIGIOSO DO EMPREGADO NO AMBIENTE DE TRABALHO: A BUSCA POR UM JUSTO EQUILÍBRIO ENTRE A MORDAÇA E O DISCURSO ABUSIVO
}

\author{
RELIGIOUS PROSELYTISM OF THE EMPLOYEE IN THE WORKPLACE: THE SEARCH FOR A \\ REASONABLE LEGAL BALANCE BETWEEN GAG AND ABUSIVE SPEECH
}

Aloisio Cristovam dos Santos Junior ${ }^{1}$

\begin{abstract}
Resumo: O objetivo do presente artigo é investigar, sob o prisma do ordenamento constitucional brasileiro e dos princípios norteadores do Direito do Trabalho, os limites ao exercício do proselitismo religioso pelo empregado no ambiente de trabalho, resguardando a sua importância para a construção e à máxima efetividade do direito fundamental de liberdade religiosa. Sustenta-se que não é lícito ao empregador colocar uma mordaça no seu empregado impedindo-o de expressar, em qualquer momento e em qualquer circunstância, as suas crenças religiosas, ainda quando este o faça com a finalidade de obter a conversão de outros frequentadores do ambiente de trabalho à sua religião. Admite-se, todavia, que as restrições ou até mesmo a vedação ao proselitismo religioso são legítimas e, portanto, afastam o dever patronal de tolerar ou acomodar a sua prática, quando manifesto o abuso de direito no seu exercício. Neste caso, o empregado que pratica o proselitismo abusivo é responsável pelos danos causados por suas ações e deve sofrer as sanções legais cabíveis.
\end{abstract}

Palavras-chave: Liberdade religiosa. Proselitismo religioso. Empregado. Ambiente de Trabalho.

\begin{abstract}
The purpose of this article is to investigate, from the point of view of the Brazilian constitutional order and the guiding principles of Labor Law, the limits to the exercise of religious proselytism by the employee in the workplace, safeguarding its importance to the construction and effectiveness of the fundamental right of religious freedom. It is maintained that it is not lawful for the employer to put a gag on his employee preventing him from expressing, at any time and in any circumstance, his religious beliefs, even if he does so for the purpose of obtaining adherents to a particular religion. However, it is accepted that the restrictions or even the prohibition of religious proselytism are legitimate and therefore exclude the employer's duty to tolerate or accommodate his practice when the employee expresses the abuse of rights in his exercise. In this case, the employee who practices abusive proselytizing is responsible for the damages caused by his actions and must suffer the proper legal sanctions.
\end{abstract}

Keywords: Religious freedom. Religious proselytism. Employee. Workplace.

Recebido em 4 de janeiro de 2019 Avaliado em 7 de maio de 2020 (AVALIADOR A) Avaliado em 30 de setembro de 2020 (AVALIADOR B) Avaliado em 29 de setembro de 2020 (AVALIADOR C)

Aceito em 2 de outubro de 2020

\section{Introdução}

De todos os conflitos que podem surgir no ambiente de trabalho tendo como móvel a expressão religiosa, não é exagerado dizer que aqueles motivados pelo proselitismo, se não são os que ocorrem com maior frequência, certamente são os mais desafiadores, na medida em que tal

\footnotetext{
1 Pós-Doutor em Direitos Humanos pela Universidad de Salamanca; Doutor em Direito pela Pontifícia Universidade Católica do Rio Grande do Sul; Professor no Centro Universitário Estácio da Bahia; Altamirando de Araújo Ramos, s/n, 43700-000, Centro, Simões Filho, Bahia, Brasil; https://orcid.org/0000-0002-0971-3205; acristovamjr@gmail.com
} 
prática, muito embora traduza simultaneamente uma afirmação da identidade do crente e uma concretização da liberdade de manifestação do pensamento, é a mais resistida de todas as posições jurídicas que compõem a liberdade religiosa.

No entanto, não é possível sustentar como regra que o empregador tenha a prerrogativa de suprimir a expressão religiosa no ambiente de trabalho. Conspira contra o reconhecimento de tal prerrogativa o respeito à autonomia e à dignidade do trabalhador crente. Na verdade, o direito de expressar a religiosidade no ambiente de trabalho, inclusive por meio do proselitismo, deve ser, em princípio, resguardado, conquanto inteiramente cabível que se lhe ponham restrições de modo a que não seja exercido de forma abusiva.

O objetivo do presente artigo é proceder à análise, sob o prisma do ordenamento constitucional brasileiro e dos princípios norteadores do Direito do Trabalho, de parâmetros objetivos que possam contribuir para a fixação dos limites ao exercício do proselitismo religioso pelo empregado no ambiente de trabalho, resguardando a sua importância enquanto posição jurídica essencial à construção e máxima efetividade do direito fundamental à liberdade religiosa.

Para tanto, inicia-se por delinear o significado do proselitismo religioso e apresentar a dúplice fundamentação constitucional que traduz a sua relevância para a construção da autonomia e para a preservação da dignidade da pessoa humana. Em seguida, sustenta-se a importância da distinção entre o proselitismo abusivo do não abusivo, mostrando, logo após, como o fenômeno pode se manifestar desde a fase pré-contratual até o derradeiro momento da existência do contrato de trabalho. Por fim, sugerem-se respostas jurídicas que visam à repressão do proselitismo religioso abusivo e a reparação do dano moral que eventualmente produza.

A metodologia utilizada na elaboração do presente trabalho consiste na revisão bibliográfica, com a pesquisa de obras nacionais e estrangeiras, e na análise do ordenamento jurídico constitucional brasileiro e da DUDH, sempre com o intuito de verificar como o reconhecimento do direito fundamental ao proselitismo religioso repercute na efetivação das liberdades de religião e de manifestação do pensamento, em especial no ambiente de trabalho. $\bigcirc$ problema central reside justamente em encontrar uma acomodação razoável do proselitismo religioso no âmbito da relação de trabalho, de modo que a liberdade religiosa e a de manifestação de pensamento do empregado não sejam emasculadas sem que haja uma justificativa racional e adequada. $O$ tema não tem sido objeto de investigação pela doutrina brasileira e mesmo no âmbito do direito comparado é pouco estudado, não obstante a sua importância para a afirmação da cidadania do empregado na empresa, que justifica plenamente uma melhor atenção por parte dos cientistas jurídicos.

\section{0 significado da expressão "proselitismo religioso"}

O termo proselitismo tem origem etimológica na palavra grega prosélutos (transliterada) que significa literalmente recém-chegado e, entre os judeus, identificava alguém que veio de uma religião 
pagã para o judaísmo. ${ }^{2}$ A conotação da palavra é, portanto, originariamente religiosa, posto que hoje se tenha tornado comum falar em outras espécies de proselitismo, dentre os quais o proselitismo político e o sindical.

À luz da raiz histórica da palavra, compreende-se proselitismo como a atividade que o crente desenvolve ao difundir, por quaisquer meios, as ideias e crenças que professa com o objetivo de conquistar novos adeptos à sua religião. ${ }^{3}$

A manifestação mais antiga e mais usual de proselitismo é a oral. ${ }^{4}$ Todavia, o proselitismo pode ser praticado na forma escrita e por meio de símbolos e gestos. ${ }^{5}$ A evolução tecnológica, ademais, permite o proselitismo à distância, com destaque para a utilização de meios de comunicação de massa, como evidenciam os inúmeros programas religiosos apresentados diariamente em emissoras de rádio e de TV do Brasil. As páginas da internet, a correspondência eletrônica e as redes sociais também têm sido largamente usadas com essa finalidade.

Há que se reter, em suma, que "proselitismo religioso" é uma expressão que identifica toda e qualquer ação promovida por um crente, independentemente da forma pela qual seja veiculada, com o desiderato de obter a conversão de outrem à sua fé religiosa. Não é outro o sentido em que se utiliza a expressão neste artigo.

\section{A raiz dúplice do proselitismo religioso: liberdade religiosa e liberdade de manifestação do pensamento}

A identidade religiosa não se restringe ao foro íntimo do crente, uma vez que lhe dota de uma cosmovisão que afeta diretamente a sua conduta, o seu modo de agir. Por isso, a liberdade de crença também compreende a liberdade de atuar conforme às crenças.

Dentre os comportamentos que derivam da autocompreensão religiosa, a divulgação das crenças com o objetivo de conquistar novos adeptos, ou seja, o proselitismo religioso, conta-se certamente como o mais resistido. Todavia, posto que com intensidade diferente, quase todas as

\footnotetext{
$\overline{2}$ Conforme registra o Evangelho de Mateus, a palavra foi utilizada por Jesus Cristo ao condenar com veemência o comportamento dos fariseus que, embora se esforçassem para conquistar adeptos à fé judaica, punham sobre o recémchegado uma carga de deveres religiosos que nem eles próprios seriam capazes de suportar. "Ai de vós, escribas e fariseus, hipócritas, porque rodeais o mar e a terra para fazer um prosélito; e, uma vez feito, o tornais filho do inferno duas vezes mais do que vós!" (Mt 23:15).

3 Sobre a definição de proselitismo, inclusive chamando a atenção para a conotação pejorativa e o preconceito que pode estar associado ao termo, cf. Guerreiro (2005, p. 177).

${ }^{4}$ Os cristãos conferem especial valor à forma oral de proselitismo, diante do ensino paulino de que "a fé vem pela pregação, e a pregação, pela palavra de Cristo" (Rm 10:17). No cristianismo, o proselitismo é frequentemente denominado de "evangelização".

5 No dizer de Rivero e Moutouch (2006, p. 524), o proselitismo assumiu historicamente diversas formas, "desde a intolerância ou mesmo a conquista até o testemunho silencioso e o martírio." Já no que tange ao alcance subjetivo do proselitismo, Cunha (2007, p. 147-148) distingue três formas pelos quais se reveste: "O mediático e de uma única e centralizada fonte para uma pluralidade de alvos anónimos; o massivo, mas directo, plural na emissão (missionária) como que porta-a-porta; e o elitista, que visa apenas certos sectores sociais (como os ricos, os pobres, ou os intelectuais)."
} 
religiões buscam divulgar as suas crenças com o objetivo de obter novas adesões. Machado (1996, p. 225) observa que:

Nem todas as religiões têm um igual impulso proselitista. No entanto, para muitas delas ele é um elemento caracterizador essencial. O cristianismo, por exemplo, tem como pedra de esquina o mandamento de Jesus Cristo, "Ide, fazei discípulos em todas as nações... até à consumação dos séculos". As Testemunhas de Jeová e os Mormons notabilizam-se pelo vigor e pela insistência dos seus esforços proselitistas. Assim, a protecção do fenómeno religioso não pode deixar de abranger os comportamentos idóneos à aquisição do consentimento e da adesão de outros à própria e à comunidade em que esta eventualmente se exprime.

A importância do direito subjetivo ao proselitismo religioso na ordem constitucional brasileira é inquestionável. Radica tanto na compreensão de que o tratamento dado à liberdade religiosa pelo texto constitucional é flagrantemente refratário a restrições à exteriorização da fé quanto na identificação da divulgação das ideias religiosas com o núcleo essencial da liberdade de manifestação de pensamento, sendo ambas as liberdades essenciais ao livre desenvolvimento da personalidade.

Nossa Constituição adota um modelo de laicidade caracterizado por uma significativa abertura para a expressão religiosa no espaço público. Com efeito, desde a referência a Deus no seu preâmbulo, ${ }^{6}$ o texto constitucional aponta para a compreensão de que o Estado brasileiro nutre indisfarçável simpatia pelo fenômeno religioso. ${ }^{7}$ A compreensão de que o modelo de laicidade do Estado brasileiro é do tipo tendente ao favorecimento da expressão religiosa - até mesmo, em alguns casos, no âmbito estatal - é, assim, a primeira sinalização de que a liberdade religiosa, no nosso ordenamento constitucional, compreende no seu feixe de posições jurídicas a prática do proselitismo.

Há, portanto, que se tomar em consideração que a expressão religiosa é um valor que integra o nosso sistema jurídico. Trata-se de um viés hermenêutico que não pode ser menoscabado, sobretudo a partir da constatação de que o Direito tem que ser interpretado sistematicamente, compreendendo princípios, regras e valores. ${ }^{8}$

\footnotetext{
${ }_{6}$ Vale registrar que ao julgar Ação Direta de Inconstitucionalidade movida pelo Partido Social Liberal, que sustentava que o preâmbulo da Constituição do Estado do Acre deveria reproduzir a invocação da proteção de Deus, o Supremo Tribunal Federal negou força normativa ao Preâmbulo da Constituição Federal, nos seguintes termos: "I - Normas Centrais da Constituição Federal: essas normas são de reprodução obrigatória na Constituição do Estado-membro, mesmo porque, reproduzidas ou não, incidirão sobre a ordem local. II - Preâmbulo da Constituição: não constitui norma central. Invocação da proteção de Deus: não se trata de norma de reprodução obrigatória na Constituição estadual, não tendo força normativa." (BRASIL, 2003). No entanto, quando o STF na mesma decisão afirma que o preâmbulo da Constituição "não se situa no âmbito do direito, mas no domínio da política, refletindo posição ideológica do constituinte", torna claro que, ainda que se lhe negue o caráter de norma central, o seu conteúdo tem implicações hermenêuticas, na medida em que evidencia uma indisfarçável simpatia do Estado brasileiro pelo fato religioso, o que, aliás, vai ser confirmado em diversos dispositivos constitucionais com força normativa.

7 Comprova-se tal afirmativa à saciedade com os dispositivos constitucionais que preveem: a prestação de assistência religiosa nas entidades civis e militares de internação coletiva (art. $5^{\circ}$, VII), a escusa de consciência por motivos de crença religiosa (art. $5^{\circ}$, VIII, e art. 143, $\int 1^{\circ}$ ), o ensino religioso nas escolas públicas (art. 210, $₫ 1^{\circ}$ ), o efeito civil do casamento religioso (art. 226, $\mathbb{S} 2^{\circ}$ ); a exceção da "colaboração de interesse público" ao princípio da separação entre Igreja e Estado (art. 19, I); a imunidade tributária quanto aos impostos incidentes sobre patrimônio, rendas e serviços das entidades religiosas (art. 150, VI, b e $\left.\int 4^{\circ}\right)$.

8 Sobre o assunto, vale recolher o ensinamento de Freitas (2004, p. 61), que define o sistema jurídico como "uma rede axiológica e hierarquizada topicamente de princípios fundamentais, de normas estritas (regras) e de valores jurídicos cuja
} 
Sob tal perspectiva, a interpretação sistemática do preceito constitucional que assegura a inviolabilidade da liberdade de crença (art. $5^{\circ}$, VI) já conduziria à conclusão de que o proselitismo jurídico corporifica um direito subjetivo contemplado no acervo de posições jurídicas do direito fundamental completo da liberdade religiosa. Isso porque - repita-se - a referência à liberdade de crença não pode ser compreendida apenas como se circunscrevesse ao foro íntimo do indivíduo, até mesmo porque a crença não externada nem mesmo é passível de controle pelo direito, que só se interessa pela conduta em interferência intersubjetiva.

A liberdade de crença de que cogita o constituinte, por óbvio, é a liberdade de manifestar a crença, de exteriorizá-la. Ademais, a liberdade de crença compreende também a liberdade de mudar de religião (SILVA, 2005, p. 249), uma faculdade que só se justifica na medida em que são afastados os eventuais óbices à livre divulgação das ideias religiosas. ${ }^{9}$

Por outro lado, a fundamentalidade do direito subjetivo ao proselitismo religioso radica também na relação indissociável que há entre tal prática e a liberdade de manifestação do pensamento ${ }^{10}$ consagrada pelo art. 5० , IV, e pelo art. 220 da Constituição Federal. ${ }^{11}$ Observa-se aí, portanto, um caso típico de concorrência de direitos fundamentais.

Há que se entender que o pensamento, como ensinam Rivero e Moutouch (2006, p. 499),

abrange tanto a apropriação das idéias prontas quanto a busca pessoal e a criação original, e isso em todos os campos, arte, ciência, moral, filosofia, religião e sob todas as formas, desde o grito elementar que traduz o entusiasmo ou a hostilidade até a obra longamente amadurecida e elaborada.

Neste sentido, é inegável que a difusão das crenças constitui corolário da liberdade de manifestação do pensamento, não diferindo essencialmente do direito que qualquer cidadão possui de externar as suas opiniões políticas ou ideológicas, ${ }^{12}$ vale dizer, de se expressar livremente sobre qualquer assunto.

função é a de, evitando ou superando antinomias em sentido amplo, dar cumprimento aos objetivos justificadores do Estado Democrático, assim como se encontram consubstanciados, expressa ou implicitamente, na Constituição."

9 É o que afirma Machado (1996, p. 225), para quem a "liberdade religiosa compreende um direito à divulgação das convicções religiosas (recht auf Äusserung religiöser Überzeugung), sem a protecção do qual a liberdade de mudar de religião não faz muito sentido."

${ }_{10}$ Utiliza-se aqui a terminologia adotada pelo constituinte brasileiro (art. 5, IV), mas não se desconhece que a liberdade de manifestação de pensamento pode ser alcunhada como liberdade de opinião, como parece preferido por franceses, ou como liberdade de expressão, havendo quem distinga e quem identifique os significados de cada uma dessas expressões.

11 Art. 5 IV - é livre a manifestação do pensamento, sendo vedado o anonimato. Art. 220. A manifestação do pensamento, a criação, a expressão e a informação, sob qualquer forma, processo ou veículo não sofrerão qualquer restrição, observado o disposto nesta Constituição.

${ }^{12}$ Dissertando sobre a liberdade de opinião, que na doutrina francesa corresponde ao que aqui chamamos de liberdade de manifestação do pensamento, Jacques Robert (1996, p. 528 apud ISRAEL, 2005, p. 485) define-a como a liberdade de cada indivíduo de adotar, em qualquer domínio, a atitude intelectual de sua escolha, quer se trate de uma atitude interior, de um pensamento íntimo ou de uma tomada de posição pública. Em suma, liberdade para cada homem de pensar e de dizer o que ele acredita ser verdadeiro. Curiosamente, as diferenças de opinião são aceitas em qualquer campo (científico, político etc.) como algo saudável e democrático. Quando se trata de divergência no campo religioso, porém, há uma enorme resistência a considerá-la democrática, havendo muita gente que acredita que o ideal é que todos tenham a mesma crença (ou não 
A conspícua estreiteza da conexão entre a liberdade de pensamento e a liberdade religiosa, inclusive, tornou inevitável que a Declaração Universal dos Direitos Humanos de 1948 tratasse de ambas no mesmo artigo:

Artigo XVIII - Todo homem tem direito à liberdade de pensamento, consciência e religião; este direito inclui a liberdade de mudar de religião ou crença e a liberdade de manifestar essa religião ou crença, pelo ensino, pela prática, pelo culto e pela observância isolada ou coletivamente, em público ou em particular. ${ }^{13}$

Como facilmente se percebe, portanto, a liberdade religiosa, sobretudo quando se projeta como liberdade de comunicar as ideias religiosas, está visceralmente imbricada com a liberdade de manifestação do pensamento. Se assim o é, não se pode negar ao proselitismo religioso ao menos a mesma proteção jurídica conferida às demais manifestações da liberdade de pensamento, ou seja, àquelas que se referem à expressão de opiniões e ideias outras que não as religiosas, como as políticas, científicas ou filosóficas.

Por sua conexão necessária com a liberdade de pensamento, fica ainda mais evidente que o direito a fazer proselitismo religioso também concretiza o princípio da dignidade da pessoa humana. A manifestação proselitista afirma a identidade do crente e, representando a tradução prática de uma convicção que refere ao transcendente, reafirma-lhe o sentido existencial.

$\mathrm{Na}$ medida em que o ordenamento jurídico constitucional brasileiro é aberto para a construção de uma sociedade democrática e pluralista e cultua a expressão religiosa como um valor jurídico, não é sequer passível de cogitação uma proibição genérica ao proselitismo religioso, o qual constitui uma posição jurídica indispensável ao desenho de dois direitos fundamentais, ambos protegidos como cláusulas pétreas, nos termos do art. 60, \ $4^{\circ}$, IV, da Constituição Federal.

Especificamente no tocante ao empregado - que é o que interessa aqui - o aspecto a ser sempre considerado quando se cogita sobre a afirmação de seus direitos fundamentais no ambiente laboral é que ele aliena a sua força de trabalho e não a sua pessoa. ${ }^{14} \mathrm{O}$ empregado, por aceitar o poder de direção empresarial sobre o seu trabalho, não abandona a sua condição de cidadão protegido pelas normas de direitos fundamentais. $\bigcirc$ ambiente de trabalho, assim, não pode ser considerado um espaço onde o trabalhador para ingressar tenha que se despir dos seus direitos fundamentais, deixando-os no lado de fora. Ao contrário, "o trabalhador deve ser considerado sempre e em primeiro lugar um ser humano detentor de direitos fundamentais" (QUEIROZ, 2012, p. 727). ${ }^{15}$

\footnotetext{
tenham crença religiosa alguma, como sugere John Lennon na letra da música Imagine: Imagine there's no countries/It isn't hard to do/Nothing to kill or die for/And no religion too).

13 Conforme reproduzido por Comparato (2005, p. 234).

${ }^{14}$ Nas palavras de Savatier (1990, p. 51), "Le travailleur n'aliène pas sa personne. Il n'en abandonne pas la direction à l'employeur. Il ne se soumet à la volonté de celui-ci que pour l'accomplissement de la tâche définie au contrat. En dehors de ce domaine, il conserve sa libertei."

15 Por isso é que hodiernamente tem sido utilizada, notadamente nos países europeus, a expressão "cidadania na empresa" para referir-se ao exercício na empresa, pelo trabalhador, de direitos fundamentais não especificamente trabalhistas. Para uma melhor compreensão do tema cidadania na empresa, vale conferir Abrantes (2005, p. 59-60) e Waquet (2003, p. 83-199).
} 
Nesse diapasão, não se concebe que seja lícito ao empregador simplesmente colocar uma mordaça no seu empregado impedindo-o de expressar, em qualquer momento e em qualquer circunstância, as suas crenças religiosas, mesmo que este o faça com a finalidade de obter a conversão de outros frequentadores do ambiente de trabalho à sua fé.

\section{Proselitismo abusivo e não abusivo: como distinguir}

Como sustentado, o comportamento proselitista não pode ser prima facie objeto da mordaça empresarial, pois constitui direito subjetivo compreendido tanto na liberdade religiosa quanto na liberdade de manifestação de pensamento, direitos fundamentais protegidos constitucionalmente, com todas as suas variadas posições jurídicas, como cláusulas pétreas. Todavia, essa constatação não implica o desconhecimento de que a prática pode suscitar conflitos no ambiente de trabalho, daí por que continua pendente a apreciação dos limites do proselitismo religioso, já que nem a sua "fundamentalidade" nem a sua ancoragem na liberdade de pensamento e no princípio da dignidade humana tornam-no, como é óbvio, um direito impermeável a restrições.

Algo que parece inegável é que o alcance das restrições ao proselitismo religioso não pode ser deixado simplesmente ao talante do poder diretivo do empregador, pois isso equivaleria ao abandono do princípio da proteção do hipossuficiente e ao aprofundamento da desigualdade entre os sujeitos do contrato de trabalho. De outro lado, o princípio da proteção não pode ser eleito como único vetor a ser considerado no exame das restrições (ou ausência de) ao proselitismo religioso, sob pena de demasiada emasculação do poder diretivo empresarial em prejuízo do desenvolvimento da própria atividade econômica.

As restrições ao proselitismo religioso no ambiente de trabalho devem ser construídas a partir do enfrentamento das contradições entre os princípios constitucionais concretizáveis por esse direito fundamental e outros princípios constitucionais que atuem nas relações travadas sob a égide do Direito do Trabalho. Com efeito, somente é aferível a legitimidade da restrição ao proselitismo religioso dentro de um contexto de colisão de princípios, no qual a prevalência de um sobre o outro depende de uma ponderação de valores que leve em conta as circunstâncias de cada caso concreto. Por outras palavras: apenas nos casos concretos será possível reconhecer se o proselitismo religioso respeita limites razoáveis e, sendo negativa a resposta, quais as providências requeridas para a adequação da prática a tais limites. ${ }^{16}$

Alguém poderia pensar que os conflitos seriam evitados facilmente a partir do reconhecimento da distinção entre o proselitismo religioso e o simples ato de externar uma convicção religiosa sem o objetivo de conquistar adeptos. Dir-se-ia que, não havendo a intenção de conquistar adeptos, a manifestação do crente seria legítima. Caso contrário, seria abusiva.

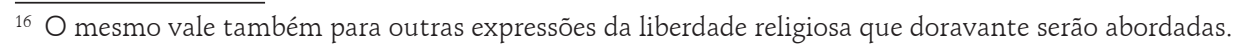


Essa distinção, porém, é impraticável. A uma, porque não é possível saber em todos os casos se a manifestação de uma opinião ou crença religiosa tem ou não o objetivo de fazer prosélitos, de modo que a questão terminará por resvalar para o foro íntimo do crente. A duas, porque não é recomendável restringir a livre manifestação do pensamento religioso com a utilização de critérios exclusivamente subjetivos que de modo algum possam ser contrastados com as normas jurídicas, sejam autônomas ou heterônomas. Acaso prevalecesse tal distinção, o enquadramento de qualquer manifestação de pensamento religioso do empregado como ato de proselitismo dependeria apenas do alvedrio do empregador ou de seus prepostos, o que na prática eliminaria o direito do trabalhador de externar as suas crenças, as quais - reitere-se - constituem parte de sua identidade e, por conseguinte, não podem ter a sua expressão proscrita sem afronta à sua dignidade.

O que vai ditar a necessidade de que a prática sofra restrições são as circunstâncias em que a mensagem é veiculada, o que inclui, por exemplo, considerações que envolvem a forma de transmissão, a natureza da atividade profissional e o perfil ideológico da organização empresarial.

Para tanto, parece útil o recurso à clássica noção jurídica de abuso do direito, avelhantada, mas nem por isso destituída de especial significado para a formulação de respostas jurídicas adequadas à solução de conflitos intersubjetivos motivados pelo aproveitamento inadequado de qualquer faculdade positivada juridicamente.

Não se desconhece que a aplicabilidade da teoria do abuso do direito ao âmbito do direito constitucional é controversa, atraindo muitas críticas cujo contexto histórico "associa-se aos intentos de utilizar-se da teoria do abuso do direito para impor limites aos direitos fundamentais em nome do interesse geral ou do Estado, moralidade, bons costumes, fins lícitos, ou segurança nacional." (WANDELLI, 2004, p. 301).

De fato, a teoria do abuso do direito, compreendida na sua concepção clássica, poderia conduzir à fragilização dos direitos fundamentais, uma vez que os interesses normalmente apontados como capazes de justificar a limitação ao seu exercício têm uma formulação genérica, permitindo toda a sorte de valorações. O que se postula aqui, portanto, é uma releitura da teoria do abuso do direito à luz da teoria dos direitos fundamentais, tarefa à qual tem se dedicado Wandelli (2004, p. 456), que explica:

A coibição do abuso do direito deve se articular a uma teoria dos direitos fundamentais [...]. Assim concebido, o abuso do direito não se presta ao esvaziamento da proteção dos direitos fundamentais, como em determinado momento histórico, mas, ao contrário, põe-se a serviço da abertura à eficácia da normatividade constitucional em âmbitos das relações privadas que a ela ainda se mantém refratários.

Sob tal prisma, em vez de aferir se o exercício de um direito fundamental contrasta com interesses genéricos que justificariam a sua limitação, o que importa mesmo é saber se no caso concreto o exercício de um direito fundamental por seu titular restringe de forma desproporcional o 
direito fundamental colidente, titulado por outro indivíduo. Compreender-se-á, então, como abusivo o exercício de um direito fundamental que cause desproporcional compressão a direito fundamental de outrem.

A distinção, é claro, vale para outras formas de expressão religiosa no ambiente de trabalho, não apenas para o proselitismo. Mas aqui ela ganha maior importância, na medida em que os maiores abusos no exercício do direito fundamental à liberdade religiosa são, certamente, aqueles que ocorrem quando alguém se esforça por levar os outros a adotar as suas próprias convicções religiosas. Assim, a partir da noção de abuso do direito fundamental é possível estabelecer a distinção entre proselitismo religioso abusivo e proselitismo religioso não abusivo, que constitui um arranjo jurídico que tanto se presta a preservar o núcleo essencial daquela posição de direito fundamental quanto a coibir os excessos no seu exercício.

Com a distinção aqui operacionalizada pretende-se enfrentar a seguinte indagação: em quais situações o proselitismo religioso do empregado, mesmo no ambiente de trabalho, merece a proteção do direito? A resposta à pergunta supõe a tentativa de identificar situações fáticas nas quais é possível vislumbrar de antemão se o proselitismo religioso está sendo exercido de forma abusiva ou não, na perspectiva da sua confrontação com outros valores e direitos que circulam no ambiente de trabalho. Trata-se, neste sentido, de um esforço que permite a visualização de alguns critérios objetivos que podem ser úteis na resolução de situações conflituosas idênticas ou similares.

Recorde-se, neste passo, que o proselitismo religioso pode partir não apenas do empregado, mas também do empregador ou de seus prepostos. ${ }^{17} \mathrm{O}$ enfoque, neste artigo, contudo, recai apenas sobre o proselitismo religioso exercitado pelo empregado. ${ }^{18}$

De qualquer modo, há momentos e/ou situações em que a prática de proselitismo pelo empregado no ambiente de trabalho não implica abuso de direito. Nesses casos, os atos de proselitismo são considerados legítimos porque, amparados em disposições autônomas ou heterônomas que compõem o conteúdo do contrato de emprego, não afetam significativamente as relações interpessoais que vicejam no ambiente de trabalho, a ponto de tornar insuportável o convívio das pessoas que ali trabalham, e nem prejudicam a atividade econômica.

Enfim, privilegiando a dogmática aplicada, a ideia aqui é identificar alguns momentos e situações em que o proselitismo do empregado pode ser considerado, em tese, legítimo ou abusivo, não se olvidando que se toma como abuso do direito fundamental o exercício de uma posição subjetiva jusfundamental que comprima um bem constitucionalmente protegido ou um direito fundamental colidente sem a observância do princípio da proporcionalidade.

\footnotetext{
${ }_{17} \mathrm{Na}$ verdade, o Direito do Trabalho foi construído justamente para compensar esse desequilíbrio. Esse ramo da ciência jurídica, nas lapidares palavras de Hernandez (2004, p. 43), "é todo centralizado no princípio da tutela 'compensatória' ao trabalhador subordinado, que consiste num conjunto de normas estabelecidas para contrabalançar a posição superior do empregador não apenas de fato, mas também juridicamente reconhecida e normativamente sustentada."

18 Sobre o proselitismo religioso do empregador cf. Santos Junior (2013, p. 299-303).
} 


\section{Os momentos de manifestação do proselitismo religioso no contexto trabalhista}

\subsection{Fase pré-contratual}

Há trabalhadores crentes - e isso é bastante comum - que não escolhem hora ou lugar para dar vazão a seu ânimo proselitista. Por isso, até mesmo os momentos prévios à celebração do contrato de trabalho podem ser utilizados para a divulgação das crenças religiosas com o objetivo de conquistar novos adeptos. Basicamente, o problema consiste em saber se os esforços proselitistas do candidato ao emprego podem ser invocados como motivo para que a sua contratação seja rejeitada.

No particular, a forma de veiculação da mensagem proselitista é determinante para a apreciação da legitimidade da recusa à contratação, mas o ponto de partida para a aferição jamais será o simples capricho do recrutador ou empregador. Se o candidato ao emprego aproveita o momento em que está sendo entrevistado para manifestar a sua inclinação ao proselitismo religioso, tentando persuadir de algum modo o recrutador a converter-se a sua fé, o empregador que invocar a tentativa de proselitismo feita pelo trabalhador como motivo para rejeição de sua contratação somente não incorrerá em discriminação religiosa se houver abuso na conduta do obreiro. Por exemplo, recusar um candidato por estar usando um Button ou uma camiseta com mensagens religiosas, sem que a empresa se trate de uma organização religiosa, confessional, de tendência antirreligiosa ou que exercite uma atividade econômica cuja realização seja incompatível com a manutenção de trabalhadores religiosos, faz presumir a discriminação pura e simples por motivos religiosos. No entanto, se a prática proselitista se manifesta de uma forma agressiva e intolerante, de modo que o aspirante ao emprego revele total desequilíbrio emocional e uma tendência à desagregação do ambiente empresarial, afigura-se legítima a recusa à contratação, pois não estará motivada pela discriminação religiosa.

Reconhece-se aqui que não será fácil para o empregado provar que foi vítima de discriminação por ter exercitado o proselitismo religioso, haja vista que o empregador poderá ocultar a verdadeira motivação da recusa em contratá-lo. Mas isso também ocorre com outras espécies de discriminação. Não se trata, ademais, de prova impossível. Muitas das dificuldades outrora existentes na produção de prova têm sido hodiernamente obviadas com o uso da tecnologia de um mero smartphone (gravação de voz, de vídeo etc.).

\subsection{Momento da conformação das cláusulas do contrato de emprego}

Se o presente artigo pretende cuidar, embora desprovido de ânimo de completude, das repercussões do proselitismo religioso do empregado, sem negar o potencial conflituoso dessa prática religiosa, uma indagação de cunho prático que se coloca diz respeito à possibilidade de estipulação de cláusula no contrato de emprego que, à partida, vede ao empregado o exercício desse direito no ambiente de trabalho, assim entendido não apenas como espaço físico onde os serviços são prestados 
mas principalmente como locus onde relações intersubjetivas são travadas no exercício da atividade profissional. $^{19}$

A resposta a tal indagação, partindo da concepção que reconhece a vinculação imediata do direito fundamental de liberdade religiosa à relação de emprego, afigura-se, de logo, negativa. Negar ao trabalhador crente o direito de expressar a sua fé religiosa nas dependências da empresa ou em outros locais onde exercita os serviços em proveito desta, mesmo que com intuito proselitista, violenta a liberdade de expressão garantida pelo texto constitucional e, em última análise, o princípio da dignidade da pessoa humana, considerando-se que a manifestação da crença é ínclita à personalidade e constitui uma afirmação da identidade do obreiro.

Registre-se, ademais, que ao empregador também é assegurado o direito de difundir suas crenças religiosas e, portanto, a estipulação de tal cláusula apenas em desfavor do empregado vulnera claramente o princípio da igualdade, sem que haja justificativa razoável para tanto. Nesse caso, o princípio da proteção estaria sendo abandonado, fortalecendo o desequilíbrio entre as partes do contrato de trabalho.

Por outro lado, se a estipulação de tal cláusula proibitiva fosse feita tendo como referência não o ambiente de trabalho, mas o momento da execução dos serviços contratualmente ajustados, ainda que não se vislumbre aí uma ofensa à liberdade religiosa do empregado, estar-se-ia com certeza diante de um nonsense jurídico. É óbvio que a prática do proselitismo religioso em substituição às atividades contratuais representa violação do pacto e justo motivo para a punição disciplinar, como ocorreria com qualquer outra atividade desenvolvida pelo empregado, no curso da jornada, que não correspondesse àquela a que se obrigou mediante contrato. Afinal, o principal dever ao qual se obriga o trabalhador quando celebra um contrato de emprego é justamente o de prestar o trabalho.

É possível inquirir, ainda, sobre o caráter absoluto ou não da proibição à estipulação de cláusula vedatória do proselitismo religioso. Ela comportaria exceções? A pergunta não é irrelevante, especialmente quando se considera - como já se observou - que instituições religiosas, que desfrutam de liberdade de autodeterminação, a principal faceta da liberdade religiosa coletiva, também assalariam trabalhadores subordinados.

Quando o empregador é uma organização religiosa, afigura-se legítima a estipulação de tal cláusula proibitiva, objetivando a que o empregado não exercite proselitismo em favor de credo antagônico ao da instituição que o assalaria? Há um robusto motivo para que a indagação atraia uma resposta afirmativa. Tratando-se de uma organização de tendência, a homogeneização ideológicoreligiosa do ambiente de trabalho é essencial para o atingimento da finalidade institucional da igreja ou do culto. A cláusula vedatória evitaria um ato de concorrência à instituição, com a difusão de ideias que contrariam os seus dogmas e que podem esvaziá-la de fiéis. Mutatis mutandi, a situação se assemelharia à negociação habitual por conta própria ou alheia praticada por empregado como ato

\footnotetext{
${ }^{19}$ A referência é necessária porque o trabalho do empregado não necessariamente é prestado no estabelecimento empresarial, podendo ser desempenhado externamente ou até mesmo no domicílio do trabalhador.
} 
de concorrência à empresa que, nos termos da alínea c do artigo 482 da CLT, constitui justa causa para a rescisão do contrato de trabalho pelo empregador. $\bigcirc$ ato de proselitismo religioso nessas condições representaria uma violação do dever de fidelidade. Esse entendimento está de acordo com a noção liberal do assim chamado mercado livre das ideias e do princípio que lhe é consectário da defesa intransigente da liberdade de expressão numa ordem constitucional livre e democrática, no contexto do pluralismo social que legitima a existência das organizações de tendência, que são formações sociais separadas do Estado que perseguem fins ideológicos. ${ }^{20}$

Outros, porém, podem objetar que a inserção no contrato de trabalho celebrado por uma organização religiosa de cláusula proibindo o proselitismo propagador de crenças contrárias à confissão do empregador seria desnecessária, pois tal cláusula já estaria implícita no pacto, como uma das condições peculiares à natureza do contratante. $\bigcirc$ argumento da desnecessidade é plausível. Só não é possível sustentar satisfatoriamente que a estipulação da cláusula contratual vedatória seja discriminatória, considerando-se que a organização religiosa também tem assegurada constitucionalmente a liberdade de autodeterminação, outra importante posição jurídica que compõe a liberdade religiosa, e a solução em tela mantém um equilíbrio razoável entre a liberdade religiosa coletiva e a individual, sempre lembrando que as organizações religiosas são veículos para a expressão da fé de indivíduos que partilham de uma crença comum e, portanto, a proteção da liberdade titulada por tais instituições concretiza, também, a liberdade dos seus associados. Ainda assim, é discutível se a vedação a toda e qualquer forma de proselitismo religioso contrário à doutrina da organização religiosa empregadora pode abranger todos os seus empregados ou se, ao contrário, algumas atividades profissionais merecem um olhar diferenciado, a exemplo daquelas desenvolvidas fora das dependências da instituição (por exemplo, um contador, contratado como empregado, que presta seus serviços no seu próprio escritório).

Merece registro aqui que há respeitáveis pronunciamentos contrários à garantia do exercício do proselitismo religioso no ambiente de trabalho. Tal posição é geralmente sustentada sob o argumento de que o proselitismo instalaria no local de trabalho um ingrediente de intolerância que poderia causar um profundo mal-estar entre os seus frequentadores, o que parece, à primeira vista, uma tentativa de aplicar ao microcosmo da relação de emprego o princípio da precaução, defendido por boa parte da doutrina ambientalista, segundo o qual deve ser evitada qualquer ação que crie o risco de dano. Silva Neto (2008, p. 158), por exemplo, sustenta que:

É exatamente em razão de situações desta natureza e com lastro na característica de intolerância conformadora da liberdade de crença que não admitimos o exercício da garantia no ambiente de trabalho. A empresa é o local para onde se dirigem os trabalhadores com o propósito de realização profissional e material, mas é indiscutível se tratar de comunidade altamente heterogênea, mais ainda quando formada por diversas categorias profissionais. A heterogeneidade

\footnotetext{
${ }^{20}$ Sobre o mercado livre de ideias, cf. Machado (2002, p. 246-255). Acerca das organizações de tendência, vale conferir Reis (2004).
} 
latente no corpo de trabalhadores abre seríssimo precedente se se possibilitar a empregado faça proselitismo de uma religião dentro da empresa, já que muitos colegas podem eventualmente ter feito a opção - ou mesmo não ter consumado escolha qualquer, o que é garantido pela Constituição, como vimos -, criando-se, assim, constrangimentos com imprevisíveis conseqüências, quer em virtude de a defesa de concepção religiosa perante quem já abraçou outro segmento significar grave ofensa à liberdade de crença, quer porque o trabalhador agnóstico pode não aceitar de modo passivo a investida do crente..$^{21}$

Ocorre, contudo, que tendência à intolerância não apenas existe no campo religioso. Existe no campo das ideologias políticas e mesmo - para utilizar um exemplo mais prosaico - na preferência por clubes de futebol. ${ }^{22}$ Há alguém que defenda que ao trabalhador não deve ser garantido o direito de tentar conquistar o voto de colegas em prol da chapa preferida nas eleições sindicais? No entanto, não raro a campanha para a eleição da diretoria de um sindicato carrega um potencial mais explosivo de intolerância que o proselitismo religioso. Não parece que a circunstância de a atividade sindical estar, em tese, relacionada à luta por melhores condições de trabalho seria suficiente para afastar a proibição do proselitismo sindical caso prevalecesse o entendimento que propugna pela supressão da livre expressão com base no risco da intolerância.

Mesmo que se venha a sustentar que a vedação ao proselitismo religioso deve ter como alvo tanto o empregador quanto o empregado - para afastar o aprofundamento do desequilíbrio entre as partes -, se a ratio da cláusula proibitiva é evitar a intolerância, como justificar a concessão de tratamento diferenciado a outras formas expressivas do pensamento, nas quais o elemento potencialmente desagregador também comparece, a exemplo do proselitismo político e de manifestações apaixonadas por clubes de futebol? Um torcedor apaixonado pelo Grêmio que tenha como colega de trabalho (ou como empregador) um torcedor fanático do Internacional - e vice-versa - sabe bem o quanto a relação interpessoal no ambiente de trabalho pode ser conflituosa logo após a disputa de um Grenal decisivo. ${ }^{23}$

Conquanto não se ignore o potencial conflituoso que a prática carrega, impedir prima facie que o empregado exercite o proselitismo religioso constitui um precedente muito mais perigoso do que lhe garantir tal possibilidade. $O$ argumento baseado na necessidade de evitar constrangimentos no ambiente de trabalho poderia facilmente ser utilizado pelo empregador para impedir a manifestação de pensamento de seus empregados a respeito de assuntos que considerasse indesejáveis, como, por

\footnotetext{
${ }^{21} \mathrm{Na}$ mesma linha de entendimento, Setubal (2011, p. 181-182), para quem o proselitismo implica incontinência de conduta a justificar a despedida por justa causa, nos termos da alínea $b$ do art. 482 da CLT.

22 Uma indagação singela, mas reveladora, é cabível: a partir das notícias veiculadas pela mídia, morrem, no Brasil, mais pessoas vítimas da intolerância religiosa, da intolerância política ou da intolerância de torcedores?

${ }^{23} \mathrm{O}$ mesmo vale para os clássicos Palmeiras v. Corinthians, Flamengo v. Vasco, Benfica v. Sporting, dentre outros. Não se desconhece que se trata de um argumento prosaico, mas considera-se aqui que os textos jurídicos devam ser escritos de um modo didático, a fim de que possam ser entendidos por leigos e não apenas por um grupo seleto de estudiosos que têm acesso ao juridiquês. Direito é, sobretudo, vida, e não um saber esotérico cujos princípios e conhecimentos não podem ser "vulgarizados" e somente devem ser compartilhados por um número bem restrito de discípulos escolhidos.
} 
exemplo, os relacionados às aspirações profissionais, o que certamente não é recomendável porque poderia causar uma erosão na luta dos trabalhadores por condições mais dignas de sobrevivência.

Madison (2003) - referindo-se às dissidências político-partidárias, mas traçando um preciso diagnóstico que vale também para outras espécies conflituosas - já alertavam que a destruição da liberdade para remediar os malefícios das facções constitui um remédio pior do que a doença.

Há [...] dois processos para remover as causas das facções: um, pela destruição da liberdade, que é essencial à sua existência; outro, fazendo com que todos os cidadãos tenham as mesmas opiniões, os mesmos sentimentos e os mesmos interesses.

Nada seria mais verdadeiro do que afirmar que o primeiro remédio é pior do que a doença. A liberdade é para as facções o que o ar é para o fogo, um elemento sem o qual elas instantaneamente se extinguem. E suprimir a liberdade - condição essencial à vida política - porque ela alimenta as facções, seria um erro não menor do que desejar a eliminação do ar, condição também essencial à vida animal porque assegura ao fogo seu poder destruidor. ${ }^{24}$

O argumento de Madison é, a um só tempo, singelo e eloquente. Na mesma linha de pensamento, é impossível não concluir que uma exegese das normas constitucionais asseguradoras da liberdade religiosa que torne possível tolher de modo absoluto o seu exercício no ambiente de trabalho constitui um remédio que cura a doença matando o doente. Trata-se de uma solução que impõe sacrifício exagerado às liberdades de pensamento e de religião, lastreando-se em razões meramente contingenciais e subjetivas. A melhor solução para o problema, que preserva a unidade do sistema jurídico, é garantir a liberdade, admitindo, porém, restrições proporcionais ao seu exercício.

\subsection{0 proselitismo religioso na execução do contrato de trabalho}

Rejeitada, por vulnerar a dignidade do trabalhador, a possibilidade de vedação absoluta do proselitismo religioso no ambiente de trabalho, excetuados talvez alguns poucos casos em que o empregador seja uma organização religiosa ou confessional e, mesmo assim, apenas quando a prática contraria a profissão de fé de tais instituições, as situações concretas vivenciadas no curso da relação de emprego é que determinarão quando se está ou não diante de um exercício abusivo de tal posição jusfundamental.

Muitas das situações que serão apresentadas aqui têm naturalmente conteúdo hipotético e não se pretende que as soluções sugeridas para os problemas que envolvem o proselitismo religioso no ambiente de trabalho tenham caráter oracular, mas apenas que indiquem possibilidades interpretativas que, por meio de precedências prima facie, não neguem a efetividade da liberdade religiosa no contrato de trabalho. Neste sentido é que o esforço aqui envidado deve ser compreendido.

\footnotetext{
${ }^{24}$ Tradução livre do texto que se encontra em The Federalist Papers, $X$.
} 
À partida, é possível de logo visualizar um parâmetro identificador de proselitismo abusivo: a sua prática em substituição às atividades contratualmente ajustadas com o empregador.

O empregado é contratado para prestar serviços e, em princípio, a prática de proselitismo em momento no qual deveria estar trabalhando constitui descumprimento de dever contratual, capaz, portanto, de ensejar a punição disciplinar e mesmo a justa causa resilitória do contrato de trabalho. Não há, neste caso, diferença no tratamento a ser dado à atividade proselitista ou a outra qualquer atividade desenvolvida com prejuízo da execução dos serviços contratualmente ajustados. No particular, tanto faz que o empregado, em vez de prestar os serviços aos quais está contratualmente obrigado, dedique-se à ação proselitista ou ao jogo de baralho.

Já foi visto que é desnecessária a estipulação no contrato de emprego de cláusula vedando a prática do proselitismo religioso em lugar dos serviços contratualmente ajustados. A prestação de serviços constitui justamente a principal obrigação contratual do empregado e é o que justifica o pagamento do salário.

Como, porém, há momentos em que o trabalhador está aguardando ordens, mas não há tarefa por executar, além do que a natureza de algumas atividades profissionais permite que o empregado em simultaneidade com a execução de algum serviço divulgue a sua fé, torna-se importante discutir se a vedação ao proselitismo religioso deve abranger não apenas o tempo em que os serviços são efetivamente cobrados, mas o tempo à disposição do empregador. A preocupação se justifica diante do preceituado no artigo $4^{\circ}$ da CLT, que considera como de serviço efetivo o período em que o empregado esteja à disposição do empregador, aguardando ou executando ordens, salvo disposição especial expressamente consignada.

Caso se considere que o trabalhador aliena ao empregador o seu tempo, a vedação ao proselitismo poderá, nesse caso, ser tida como legítima. Mas não é assim. A intenção do dispositivo em questão não é modificar o objeto do contrato de trabalho, que será sempre a energia despendida pelo empregado, isto é, a prestação de serviços, e não o tempo posto à disposição do empregador. A equiparação legal entre o tempo em que o trabalhador está aguardando ordens e o tempo em que as executa visa à sua proteção, não permitindo que a contraprestação salarial fique totalmente à mercê da boa vontade do empregador de proporcionar-lhe serviços a serem executados, não podendo o dispositivo em questão ser interpretado, sem dano ao princípio da proteção e à dignidade do trabalhador, de modo a conferir ao empregador a prerrogativa de restringir a sua liberdade de expressão. Se o objeto do contrato de trabalho fosse o tempo disponibilizado e não o serviço a ser prestado, o empregador estaria autorizado a cobrar do empregado a execução de tarefas totalmente estranhas à sua qualificação profissional.

À primeira vista, porém, a vedação deve ser mantida quando o proselitismo religioso praticado no tempo à disposição do empregador ou em simultaneidade com a execução de alguma tarefa (ao mesmo tempo e não $\mathbf{e m} \boldsymbol{v e z} \mathbf{d e}$ ) se revela prejudicial à qualidade ou à quantidade dos serviços, causa constrangimentos a outrem (colega, cliente, empregador) ou gera transtornos 
significativos para as relações interpessoais no ambiente de trabalho. É fácil perceber em situações quejandas a quebra do dever de diligência ou do dever de urbanidade, além dos reflexos negativos para a atividade empresarial, cuja eficiência depende muito da saúde emocional dos empregados.

Uma coisa é certa, porém. Se o empregado utiliza o tempo à disposição do empregador para a prática de proselitismo religioso em vez de executar os serviços contratualmente ajustados, salvo permissão especial que este lhe conceda, não há qualquer dúvida de que incorre em falta contratual. A contraprestação que o empregado recebe do empregador, ainda que a forma de seu cálculo possa considerar o tempo, tem como sinalagma a prestação dos serviços. Esta, sim, é que constitui a principal obrigação contratual do trabalhador, contraída legitimamente por meio da expressão de sua vontade autônoma, com base na liberdade que o ordenamento constitucional the confere. Se, em vez de prestar o seu serviço, o empregado dedica-se a uma atividade religiosa não autorizada por seu empregador, há uma sinalização clara de grave infração contratual.

Isso vale, também, quando o empregado, embora execute os trabalhos a que se propôs contratualmente, faça-o de forma negligente, por estar com a sua atenção focada para a realização do objetivo religioso. De fato, não apenas o proselitismo que redunda no descumprimento da obrigação de prestar os serviços deve ser considerado abusivo. De igual modo, o proselitismo que diminui a eficiência na prestação de serviços, que ocorre quando o empregado deixa de executar diligentemente as tarefas a que está contratualmente obrigado por conferir demasiada atenção à prática religiosa. Neste caso, o abuso configura uma quebra do dever de diligência.

Não é impossível, porém, que o empregador permita ou tolere o proselitismo realizado pelo empregado durante o tempo efetivo de prestação de serviços. ${ }^{25}$ É claro que há atividades que, por sua própria natureza, não permitem sejam realizadas simultaneamente com atos comunicativos de propagação da fé religiosa. Certas atividades que exigem isolamento do trabalhador ou um elevado grau de atenção podem ser refratárias à manifestação - por meio da voz, da escrita, dos gestos ou de outras formas de comunicação - de qualquer mensagem proselitista. Não parece crível, por exemplo, que se possa desarmar uma bomba-relógio e simultaneamente fazer proselitismo religioso. Mas há outras atividades para as quais não há óbice material a que sejam desenvolvidas ao mesmo tempo em que a mensagem proselitista é veiculada.

Se o ato de proselitismo religioso no ambiente de trabalho não se torna abusivo só pelo fato de inexistir no contrato de emprego cláusula que o permita, porquanto sua legitimidade deriva do texto constitucional e não pode ser elidida por cláusula contratual, é certo que quando a prática é permitida pelo empregador, expressa ou tacitamente, por ocasião da admissão ou no curso do pacto laboral, ainda que realizada simultaneamente com a prestação de serviços (ou eventualmente em lugar da prestação de serviços, por uma concessão especial do empregador), não poderá este

\footnotetext{
${ }^{25}$ Repita-se que, nos termos do art. $4^{\circ}$ da CLT, "Considera-se como de serviço efetivo o período em que o empregado esteja à disposição do empregador, aguardando ou executando ordens, salvo disposição especial expressamente consignada." (BRASIL, 1943).
} 
posteriormente imputar-lhe a pecha de ilícito contratual. A prática até poderá ser abusiva em face de terceiros (colegas de trabalho, clientes etc.) aos quais cause constrangimento, mas o empregador - ou o seu sucessor - não poderá, mudando de opinião, pretender a punição do empregado por atos pretéritos aos quais lhe foi dada permissão.

Registre-se que, mesmo que conte com a permissão do empregador e seja realizado fora da jornada de trabalho, o proselitismo será abusivo quando afeta negativamente a rotina do trabalho e cria constrangimento para os colegas ou para os clientes da empresa. Como visto, é possível que o empregador não crie qualquer obstáculo - ou até dê permissão expressa - para que o empregado, simultaneamente com a execução dos serviços, exercite livremente o seu ânimo proselitista. Não constitui fato incomum e pode ser motivado pelo impulso proselitista do próprio empregador. Ainda assim, o empregado crente não pode exercitar o seu proselitismo de um modo tal que cause constrangimento aos colegas ou aos clientes da empresa que não gozam da mesma fé ou mesmo que não professem fé alguma.

Rara será a permissão concedida pelo empregador quando da contratação do empregado, mas não é impossível que ocorra na prática. Um trabalhador extremamente qualificado e tido pela empresa como indispensável para o funcionamento de uma unidade produtiva poderá condicionar sua própria contratação à permissão para que possa expressar livremente a sua fé no ambiente de trabalho ainda que com intuito proselitista, desde que cumpra as metas de trabalho traçadas pelo empregador. A necessidade da empresa poderia forçá-la a aceitar tal condição. Quem conhece o zelo e o fervor religioso que animam muitos trabalhadores não considerará cerebrina a hipótese de que algum deles chegue a formular uma exigência neste sentido.

Um exemplo hipotético pode ilustrar a situação. Suponha-se que uma emissora de rádio especializada em programas esportivos esteja prestes a perder os seus principais anunciantes caso não consiga contratar um locutor de futebol renomado. Conhecendo um profissional competente, que preenche todas as qualificações para elevar o ibope da emissora, oferece-lhe a vaga de emprego. O locutor, então, diz que aceita o emprego, mas, motivado por seu ímpeto missionário, impõe uma condição: que durante as transmissões esportivas possa dispor de quinze segundos para expressar nos microfones uma curta mensagem que veicule a sua fé. Se a emissora de rádio aceita a condição, está estabelecida uma cláusula de permissão ao proselitismo religioso mesmo que ocorra em simultaneidade com a prestação de serviços.

Não é difícil, porém, imaginar outras situações em que poderá haver uma permissão expressa para que o trabalhador exercite o proselitismo religioso no ambiente de trabalho em simultaneidade com a atividade laboral. A contratação do trabalhador pode ser motivada pelo fervor religioso do empregador, que tem nele um aliado para a disseminação de suas crenças no ambiente de trabalho. Eventuais problemas que isso provoque nas relações entre o empregador e os demais empregados que não compartilhem da mesma fé não tornam inválida a cláusula permissiva que consta do contrato específico daquele trabalhador. 
Entretanto, certamente são maiores as chances de que o empregador permita o proselitismo religioso do empregado no curso do contrato de emprego, tempos após a sua celebração. Também aí pode acontecer que o ânimo proselitista do empregador, manifestado em momento superveniente à contratação, seja o motivo determinante da permissão, que pode ser expressa ou tácita. O empregador pode favorecer a prática proselitista de um empregado simplesmente por este pertencer ao seu credo e estar motivado por igual ardor missionário. Não é incomum, ademais, que um empregado crente conquiste a permissão do empregador para exercitar o proselitismo religioso, mesmo no tempo contratualmente destinado à prestação dos serviços, em função de que a sua postura discreta, elegante e pacificadora ao expressar a espiritualidade, longe de produzir conflitos, torna-o uma influência positiva no ambiente de trabalho, deixando-o mais harmônico e contribuindo para o sucesso da atividade empresarial.

Nesse contexto, uma interessante questão diz respeito à possibilidade de que a permissão ao proselitismo religioso se incorpore ao conteúdo do contrato de trabalho. A permissão ao proselitismo concedida em momento superveniente à contratação do empregado, nas situações em que o empregador poderia vedá-lo, pode vir a integrar o contrato de trabalho de modo a que não mais seja possível tratá-lo como ilícito contratual?

Uma resposta possível é a de que, por favorecer ao empregado religioso, a permissão ao proselitismo passa a integrar o seu contrato de trabalho e não mais lhe poderá ser negada, diante do princípio da condição mais benéfica. Neste caso, o direito à manutenção da permissão poderia ser invocado perante o sucessor empresarial. Mas isso somente faz sentido se a prática não afeta a eficiência do trabalho e o desenvolvimento da atividade empresarial e nem vulnera a liberdade de consciência dos colegas e de outros frequentadores do ambiente de trabalho. A permissão poderia, inclusive, ocorrer de modo tácito: se o empregador passa a tolerar por tempo considerável o comportamento proselitista do empregado, ter-se-ia a cláusula como acrescida ao contrato de trabalho.

Obviamente, a prática proselitista capaz de se integrar ao contrato de trabalho como uma condição mais benéfica é aquela exercitada quando a natureza do trabalho permite a simultaneidade das ações, como visto no exemplo do locutor esportivo, tratando-se sempre de situações em que o empregador poderia validamente, caso desejasse, proibir o exercício do proselitismo religioso. Em qualquer caso, porém, desde que não cause constrangimento aos colegas ou clientes da empresa. A discussão não faz sentido quando o proselitismo prescinde da permissão do empregador.

Ilustre-se com outro exemplo. Suponha-se que uma livraria não se oponha a que determinado empregado, excelente vendedor, faça propaganda de sua fé evangélica enquanto desempenha as suas atividades profissionais. A empresa, embora pudesse restringir a atividade religiosa do trabalhador pelo simples fato de que está sendo realizada simultaneamente com a prestação de serviços, permite a prática por considerar que ele exercita o proselitismo religioso com simpatia e discrição, respeitando o direito dos colegas e dos clientes de não ouvirem o discurso caso não o desejem. Ademais, a prática não afeta as suas vendas, que são muito maiores que às dos demais vendedores. Os anos se 
passam e não há qualquer problema. Certo dia há uma mudança na direção da loja e o novo gerente determina àquele vendedor que se abstenha de fazer qualquer propaganda, ainda que discreta, da sua fé religiosa, porque não tolera expressão religiosa alguma no ambiente de trabalho. Aparentemente, ocorreu aí uma permissão tácita que se incorporou ao contrato de trabalho do empregado, de modo que suprimir a sua expressão religiosa agora, se feita nas mesmas condições anteriores, representará uma alteração contratual lesiva ao trabalhador.

Por outro lado, a licença do empregador para que o empregado pratique proselitismo religioso constrangendo os colegas de trabalho e os terceiros que frequentam o ambiente de trabalho deve presumir-se sempre precária, pois, ainda que, por conta da permissão empresarial, deixe de configurar ilícito contratual, continuará sendo um comportamento que repugna ao ordenamento jurídico, não se podendo jamais incorporar ao pacto laboral. A mudança de opinião do empregador ou a chegada do sucessor empresarial impondo limites ao proselitismo deve ser considerada lícita.

De igual modo, a prática de proselitismo em vez da prestação de serviços, por mais que seja tolerada pelo empregador, não pode gerar direito ao empregado. Nesse caso, a ilicitude contratual permanece, pois a obrigação básica do empregado no contrato de trabalho é a prestação de serviços e não a prática de proselitismo religioso. A permissão do empregador não pode ser interpretada como novação objetiva, mas como tolerância precária, destituída de caráter definitivo, já que a substituição da obrigação básica de prestação de serviços por um dever religioso importa descaracterização do contrato de emprego, além de representar quebra de isonomia de tratamento entre os empregados. Não há aí, portanto, direito a ser invocado perante o empregador e nem perante o sucessor empresarial. $\bigcirc$ novo empregador não está obrigado a aceitar essa condição e o empregado, caso continue a realizar o proselitismo religioso em vez de prestar os seus serviços, estará sujeito ao poder disciplinar empresarial, incluindo a resolução do contrato de trabalho por justa causa.

Há que se considerar, em qualquer circunstância, que o proselitismo deve ser sempre exercitado sob a consideração de que há dois direitos que merecem igual respeito: (1) o direito de quem, impelido por sua própria fé, exercita essa prática, e (2) o direito de quem é alvo do proselitismo de manter a sua fé (ou falta de).

Se o proselitismo abusivo se dá com o conhecimento do empregador, que o chancela com a sua permissão expressa ou com seu silêncio conivente, é inegável que o empregado que é submetido ao constrangimento moral decorrente da ação de seu colega, a par de solicitar à empresa providências que se dirijam à coibição do abuso, poderá também responsabilizá-la diretamente pelos danos sofridos. Está na esfera do poder disciplinar do empregador (uma das manifestações do poder diretivo) reprimir quaisquer constrangimentos que um empregado cause a outro no ambiente de trabalho.

À semelhança do que ocorre na relação entre cidadão e Estado, também na esfera da relação de emprego há que se reconhecer a existência de um dever de proteção que onera a parte que se encontra em posição de superioridade, como um consectário da obrigação de manter um ambiente de trabalho 
seguro e digno, que garanta a integridade não apenas física, mas emocional, dos trabalhadores. Sob tal perspectiva, cabe ao empregador não apenas respeitar os direitos fundamentais dos seus empregados, mas também zelar por sua proteção. A jurisprudência trabalhista, inclusive do TST, não ignora a existência desse dever, considerando-o como um dos deveres acessórios do contrato de trabalho, embora os julgados refiram-se geralmente aos direitos à saúde, ao meio-ambiente de trabalho saudável, à segurança e à intimidade, ${ }^{26}$ não havendo registro nos anais da mais alta corte trabalhista de uma decisão que trate especificamente do dever de proteger os empregados da coerção religiosa.

Observadas as situações que, em tese, o proselitismo religioso praticado pelo empregado é abusivo, torna-se mais fácil chegar às situações em que o proselitismo religioso não o é. De certo modo, trata-se de um processo de exclusão. Toda a prática proselitista que não configura abuso será, a contrario sensu, legítima. Isso não torna, porém, desnecessária a adução de alguns comentários alusivos a situações concretas que podem reforçar a compreensão do tema.

A prática de proselitismo religioso pelo empregado pode ser considerada não abusiva quando realizada durante os intervalos intrajornada. Com efeito, desde que o empregado esteja usufruindo dos intervalos para descanso e para refeição, a prática proselitista, ainda que efetuada no espaço físico da empresa, não pode ser, em princípio, considerada abusiva e, assim, prescinde da permissão do empregador.

É possível argumentar que não seria legítimo o proselitismo no intervalo intrajornada porque se trata de um tempo destinado ao descanso, para que o empregado recobre as suas energias. No entanto, tal argumento não resiste à simples constatação que a energia despendida com o discurso proselitista é a mesma - eventualmente até menor - que a energia gasta numa discussão sobre futebol ou sobre preferências políticas, o que, mais uma vez, levanta a seguinte pergunta: por que tratar de forma diferente a comunicação somente pelo fato de ter caráter religioso? Demais disso, o descanso semanal remunerado, cuja finalidade precípua é o revigoramento adequado de energias e o convívio social e familiar, também se presta à prática religiosa congregacional e jamais se cogitou que a atividade religiosa pudesse ser considerada um obstáculo à recuperação das energias do empregado, até por causa de sua relevância para a saúde emocional do trabalhador religioso.

É claro, porém, que se o alvo do proselitista é um colega que não está gozando do intervalo e tem o rendimento do seu trabalho prejudicado por conta disso, a situação é diferente. Mas não é o ato em si de fazer proselitismo no ambiente de trabalho que torna ilegítima a prática, e sim o fato de estar o empregado religioso interferindo na qualidade e na quantidade do trabalho de um colega e, por conseguinte, causando prejuízo à empresa. Na melhor das hipóteses, tal conduta vulnera o

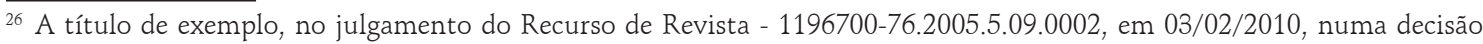
relatada pela Ministra Rosa Maria Weber, a $3^{a}$ Turma do TST considerou abusivo o procedimento de revista íntima ao qual uma empresa submetia os empregados, que juntamente com a vistoria de suas bolsas e mochilas tinham seus corpos apalpados por seguranças, entendendo que o empregador violou o dever de proteger a integridade física e psíquica do empregado. Já no processo AIRR - 175740-70.2005.5.04.0030, julgado em 04/03/2009, a 7a Turma, em acórdão relatado pelo Ministro Guilherme Augusto Caputo Bastos, entendeu que a empregadora falhou no seu dever de proteção do ambiente de trabalho, uma vez que a reclamante caiu de uma escada que não possuía corrimão nem mecanismo antiderrapante.
} 
dever de diligência. Também aí continua valendo, por óbvio, a exigência de que os atos proselitistas devem sempre respeitar o direito de quem é alvo do proselitismo de afirmar a sua fé (ou falta de) e recusar-se a ouvir o discurso.

O proselitismo religioso pode, também, ser tido como não abusivo quando realizado com discrição de modo que não afete a rotina do trabalho, a quantidade e a qualidade dos serviços prestados e nem crie constrangimento para os colegas ou para os clientes da empresa.

Em verdade, mesmo quando ocorrem durante a jornada de trabalho, alguns comportamentos proselitistas são realizados com tal discrição que não afetam a rotina de trabalho e nem criam constrangimento para os colegas ou para os clientes da empresa. Algumas formas de proselitismo, inclusive, podem ser bastante silenciosas. É o caso, por exemplo, da utilização pelo empregado de buttons ou mesmo de camisetas com estampas que veiculem mensagens religiosas.

Essas formas silenciosas de proselitismo, em princípio, não devem ser tidas como abusivas, firmando-se em seu favor a presunção de que a mensagem veiculada não causará constrangimentos aos colegas e clientes da empresa e nem qualquer prejuízo ao empregador. Há, contudo, exceções que servem para confirmar a regra. Algumas mensagens religiosas veiculadas por meio de camisetas podem, sim, causar prejuízo ao empregador e, eventualmente, provocar distúrbios no ambiente de trabalho. Não podem ser, ainda que silenciosas, reconhecidas como expressão legítima de proselitismo. Observe-se, por exemplo, o comportamento de um vigia de motel que ostente na sua camiseta estampa com caracteres fosforescentes contendo uma frase desse tipo: "Deus condena os adúlteros. Arrependam-se para não serem lançados no fogo do inferno". Conquanto o meio da divulgação da mensagem seja silencioso, um ato de proselitismo dessa natureza certamente não pode ser considerado discreto.

Por outro lado, é possível que os serviços realizados no ambiente de trabalho, que constituem a razão da contratação de empregados pela empresa, não sofram qualquer prejuízo pela prática proselitista, especialmente diante da natureza de algumas atividades e profissões. Uma enfermeira que, trabalhando numa clínica para dependentes químicos e desempenhando as suas funções com eficiência e presteza, aproveita alguns momentos em que está assistindo um paciente com tendências suicidas para convencê-lo, na tentativa de salvar-lhe a vida, de que a fé em Deus poderá fazê-lo superar seus problemas, pratica uma ação proselitista que não afeta a qualidade e nem a quantidade dos serviços do estabelecimento de saúde e aparentemente vai ao encontro do objetivo principal da atividade médica, que é a cura do paciente.

\section{0 proselitismo religioso por meio de mensagens eletrônicas}

O desenvolvimento tecnológico tem trazido significativas mudanças na forma de comunicação entre as pessoas, o que inevitavelmente repercute no mundo empresarial, onde a 
transmissão de informações é essencial para o desenvolvimento de qualquer atividade econômica e, naturalmente, afeta as relações de trabalho.

Atualmente, a correspondência eletrônica é um dos recursos mais utilizados para a comunicação no meio profissional. Muitas empresas mantêm e-mails corporativos, sendo comum, ademais, que promovam a criação de listas e grupos na internet formados apenas por seus empregados.

A utilização ampla desse meio de comunicação desafia algumas indagações relacionadas com a proteção à privacidade, a livre expressão das ideias no ambiente virtual, mas também com os limites do poder diretivo do empregador.

A abordagem do problema passa, inicialmente, pela indagação sobre a legitimidade do monitoramento pelo empregador do conteúdo da correspondência eletrônica do empregado. ${ }^{27}$

Em princípio, tratando-se de e-mail pessoal do empregado, vale dizer, que não é disponibilizado pela empresa como ferramenta de trabalho, ainda quando utilizado com os recursos institucionais do empregador (computadores, acesso à internet etc.), a melhor resposta é a que postula por sua indevassabilidade, em virtude dos direitos à privacidade e ao sigilo de correspondência que protegem o obreiro enquanto cidadão. ${ }^{28}$ Como observa Belmonte (2004, p. 79),

O e-mail particular é meio de comunicação de natureza estritamente pessoal e, portanto, inviolável. Nessa qualidade, somente podendo ser vasculhado mediante prévia autorização, do próprio empregado ou ainda judicial, na última hipótese se entendido que não fica limitada à instrução processual penal, podendo ser estendida aos processos civil e trabalhista. Qualquer intromissão material não autorizada será considerada invasão de intimidade e, especificamente, quebra de sigilo de correspondência ou violação da intimidade, vulnerando direitos fundamentais do trabalhador e dando ensejo a reparações inibitórias e de cunho patrimonial e moral.

Quanto ao e-mail corporativo, constituindo-se ele numa ferramenta de trabalho destinada à utilização em serviço, a doutrina e jurisprudência têm aceitado que o empregador exercite controle sobre o conteúdo das mensagens veiculadas, ${ }^{29}$ embora não haja um consenso sobre os limites que podem ser impostos ao seu uso pelo empregado.

Interessa aqui apenas o problema da transmissão de mensagens religiosas proselitistas. $\mathrm{Na}$ linha de pensamento aqui seguida que distingue o proselitismo abusivo do não abusivo, impende observar que a utilização, para o anúncio de ideias religiosas, do meio eletrônico disponibilizado pelo empregador não será, por si só, abusiva. A ocorrência ou não do abuso deve ser apreciada caso a caso.

\footnotetext{
${ }^{27}$ Cf. sobre o assunto Ruaro e Sarlet (2006, p. 227-252).

${ }^{28}$ Esta posição encontra acolhida, inclusive, na jurisprudência francesa, que fixou o entendimento de que a correspondência eletrônica particular do empregado é inviolável, ainda quando são utilizados os computadores da empresa (Cour de Cassation - Chambre sociale. Arret, n. 4164 du 2 Oct. 2001).

${ }^{29}$ Como afirma Andrade (2009, p. 174), "a jurisprudência brasileira orienta-se, predominantemente [...] considerando viável a verificação de e-mails expedidos pelo empregado, pelo empregador, e, em consequência, validando demissões de funcionários por justa causa, não obstante sejam normalmente acrescidos determinados pressupostos como o aviso prévio aos empregados, ou a configuração de hipóteses graves de quebra de fidúcia, como serve de exemplo a situação em que se flagrou o uso da correspondência eletrônica pelo empregado para o envio de fotos pornográficas."
} 
No entanto, há que se presumir, como regra, que o meio eletrônico fornecido pelo empregador para uso no ambiente de trabalho deve servir apenas para comunicações relacionadas com o exercício da atividade profissional. Assim, se é vedada a veiculação de qualquer mensagem que não diga respeito ao trabalho, obviamente a mensagem religiosa inclui-se na proibição.

Todavia, se o empregador tem uma política de tolerância com a utilização do meio eletrônico e permite a veiculação de mensagens de qualquer natureza, como anedotas ou mensagens de cunho político-eleitoral, não haverá como, a menos que a natureza da empresa ou a sua atividade econômica o autorizem, dar tratamento diferenciado à mensagem religiosa. Se o empregador permite, por exemplo, que os empregados utilizem o e-mail corporativo para fazer proselitismo político, sindical, ou para expressar a paixão por um clube de futebol divertindo-se à custa do torcedor do time adversário, por que lhe será lícito coibir apenas a veiculação de mensagens religiosas?

É certo, porém, que se a mensagem religiosa é veiculada com agressividade ou desprezo pelos colegas que professam outras crenças, traduzindo discurso de ódio, a intromissão do empregador se justifica visando à manutenção de um ambiente de trabalho harmônico e saudável. Mas não será o simples fato de ser religiosa, num contexto de tolerância à expressão de ideias diversas, que autorizará a vedação. Uma proibição dirigida especificamente à expressão de mensagens religiosas, quando se permite a difusão ampla de ideias por conduto do e-mail corporativo, independentemente de que sejam relacionadas com o trabalho, poderá vir a ser considerada uma hipótese de discriminação por razões religiosas.

\section{Efeitos do proselitismo religioso abusivo no contrato de trabalho}

O empregado que exercita abusivamente o proselitismo religioso está suscetível à despedida por justa causa e à obrigação de reparar o eventual dano moral impingido àqueles que foram alvo de seu discurso.

\subsection{Justa causa resilitória do contrato de trabalho}

A prática do proselitismo abusivo ou do assédio religioso pelo empregado constitui infração contratual que, dependendo das circunstâncias em que ocorra, pode enquadrar-se numa ou mais das figuras de justa causa resilitória do contrato de trabalho previstas no art. 482 da CLT. Com efeito, tal conduta pode amoldar-se, sem maiores dificuldades, às alíneas "a" (mau procedimento), "e" (desídia) $\mathrm{e}$ "h" (indisciplina ou insubordinação) do citado dispositivo legal.

O mau procedimento é, por excelência, a justa causa mais adequada para o enquadramento do proselitismo abusivo e do assédio religioso, sobretudo por constituir fórmula bastante elástica. A correspondência entre o mau procedimento e as práticas indigitadas é facilmente percebida nas 
definições que a doutrina trabalhista construiu em torno dessa justa causa, sobre o que já se falou no capítulo anterior.

A desídia, que consiste na violação do dever de diligência do empregado, pode também caracterizar abuso, quando este, por valorizar demasiadamente o seu esforço religioso, negligencia reiteradamente a obrigação contratual básica do contrato de emprego, reduzindo a qualidade e/ou a quantidade dos serviços prestados. Trata-se de justa causa que, segundo o magistério de Gomes e Gottschalk (2004, p. 371), requer a apreciação da conduta do empregado, vale dizer, a repetição de atos indicativos da falta de eficiência ou diligência.

A indisciplina e a insubordinação consubstanciam violação de um dever de obediência. No primeiro caso, a desobediência dirige-se a uma disposição genérica tomada pelo empregador. No segundo caso, a desobediência se refere a uma ordem específica. Não é difícil imaginar situações em que uma ação proselitista por parte do empregado representa desobediência a um desses deveres. Por exemplo, se a organização religiosa empregadora edita um regulamento, dirigido a todos os seus empregados, proibindo que façam propaganda de outros credos no ambiente de trabalho, o ato de proselitismo do empregado implica insubordinação. A desobediência pode caracterizar-se, por exemplo, quando o superior hierárquico de um empregado, percebendo que sua prática proselitista está constrangendo os clientes da empresa, determina que ele pare de exercitá-la e o obreiro recusa-se a cumprir a ordem.

Eventualmente, a forma agressiva ou virulenta com que o ato de proselitismo é veiculado pode vir a caracterizar as justas causas previstas nas alíneas j e $k$ do artigo 482 da CLT, que se referem a atos lesivos da honra ou boa fama praticados no serviço ou a ofensas físicas: no primeiro caso, contra qualquer pessoa (colegas ou clientes da empresa, por exemplo); no segundo caso, contra o empregador. Há que ser mais uma vez lembrado, porém, que as ofensas físicas, por si mesmas, independentemente do motivo que as originou, já constituirão justa causa resilitória.

Registre-se, ainda, que há pronunciamento respeitável no sentido de que a prática de proselitismo religioso abusivo enquadrar-se-ia na alínea " $b$ ", do artigo 482, da CLT. ${ }^{30}$ Se a incontinência de conduta for entendida como um ato faltoso que se configura pela carência de pudor, exteriorizado pela prática, em serviço, de gestos, palavras e atos obscenos contra qualquer pessoa (BARROS, 2007, p. 871), parece inapropriado o enquadramento. Todavia, há uma forte corrente doutrinária, na linha do entendimento esposado por Gomes e Gottschalk (2004, p. 370), que confere sentido mais amplo à incontinência de conduta, distinguindo-a do mau procedimento apenas pela extensão física do ambiente em que a falta é praticada, assemelhando-os "por se tratar de faltas inerentes ao modo de ser da pessoa, suas relações para com terceiros, a conduta, enfim do individuo."

\footnotetext{
$\overline{30}$ É o posicionamento de Silva Neto (2008, p. 159), observando-se, porém, que na sua visão todo proselitismo religioso é um abuso.
} 


\subsection{Reparação por dano moral}

É discutível se o proselitismo abusivo constitui sempre um ato lesivo da honra, que constitui um dos bens jurídicos cuja violação implica dano moral, embora seja certo que, dependendo da forma em que a mensagem é veiculada pelo crente, o ato de proselitismo religioso poderá vir a representar um ataque à reputação daquele que é alvo da prática. Ocorre, porém, que o sofrimento moral não é impingido apenas quando a honra é vulnerada. Não é preciso que o proselitista dirija à sua vítima palavras injuriosas ou o acuse de um fato, criminoso ou não, que desabone a sua reputação, para que fique configurado o dano moral. Diversas outras situações que dizem respeito tanto ao bem ou direito personalíssimo afrontado quanto ao efeito não patrimonial de uma lesão a direito subjetivo patrimonial podem caracterizar o dano moral.

A atividade proselitista abusiva do empregado, porém, não necessariamente provoca um dano moral ao seu destinatário. De fato, o abuso na prática do proselitismo pelo empregado não se dá apenas em razão de constrangimentos morais que cria para o destinatário de sua mensagem, pois pode representar apenas o descumprimento de obrigações contratuais legítimas relacionadas com o tempo destinado à execução dos serviços, com a natureza da atividade laboral contratada ou com as finalidades institucionais do empregador. Tome-se como exemplo a situação em que o empregado pratique com discrição o proselitismo $\mathbf{e m}$ vez de prestar os serviços a que está contratualmente obrigado. Há aí um abuso consistente em infração contratual capaz de ensejar punição disciplinar - inclusive a dispensa por justa causa - sem que o propagador religioso tenha causado qualquer sofrimento moral a alguém.

\section{Conclusão}

O proselitismo religioso, enquanto tradução da liberdade religiosa e da liberdade de manifestação de pensamento, direitos fundamentais que o empregado preserva no ambiente de trabalho, constitui direito subjetivo cujo exercício é essencial ao livre desenvolvimento de sua personalidade.

Por tal razão, é insustentável o argumento de que o empregador tem a prerrogativa de criar um ambiente de trabalho totalmente asséptico à expressão religiosa proselitista. Isso representaria na prática, nada mais, nada menos, que colocar uma mordaça no trabalhador, num brutal desrespeito à sua identidade e à sua dignidade pessoal sem uma justificativa razoável.

É necessário que se entenda que o poder diretivo do empregador tem um caráter instrumental em relação à atividade empresarial. Ele é instituído em benefício da condução dos negócios, isto é, da consecução dos fins visados pela atividade econômica e não para a satisfação de caprichos do empregador. A ideia de que qualquer expressão religiosa deve ser ipso facto suprimida do ambiente de trabalho, ademais, nada tem de libertária. Antes, é um retrocesso aos primórdios da Revolução 
Industrial, quando a busca desenfreada pelo lucro não respeitava os direitos de personalidade do empregado.

No entanto, o proselitismo religioso, como qualquer posição jurídica subjetiva, deve ser praticado de modo a não configurar o abuso de direito, o que implica necessariamente que o empregado deverá respeitar restrições racionalmente fundadas ao seu exercício. O que vai ditar a necessidade de que a prática sofra restrições, contudo, não é - repita-se - o mero capricho do empregador. As circunstâncias em que a mensagem é veiculada - o que inclui, por exemplo, a forma e o momento de sua transmissão -, a natureza da atividade profissional e o perfil ideológico da organização empresarial é que justificarão a amplitude das restrições ao proselitismo religioso do empregado.

Por fim, impende repisar que o abuso na prática do proselitismo atrai o exercício legítimo do poder disciplinar do empregador e pode fazer nascer para o empregado o dever de reparação de eventual dano moral que tenha infligido aos destinatários de seu discurso.

\section{REFERÊNCIAS}

ABRANTES, José João. Contrato de trabalho e direitos fundamentais. Coimbra: Coimbra Editora, 2005.

ANDRADE, Fábio Siebeneichler. Considerações sobre o desenvolvimento dos direitos da personalidade e sua aplicação às relações do trabalho. Revista Direitos Fundamentais e Justiça, v. 6, p. 162-176, 2009.

BARROS, Alice Monteiro de. Curso de direito do Trabalho. 3. ed. rev. e ampl. São Paulo: LTr, 2007.

BELMONTE, Alexandre Agra. O monitoramento da correspondência eletrônica nas relações de trabalho. São Paulo: LTr, 2004.

COMPARATO, Fábio Konder. A afirmação histórica dos direitos humanos. 4. ed. rev. e atual. São Paulo: Saraiva, 2005.

CUNHA, Paulo Ferreira da. A constituição viva: cidadania e direitos humanos. Porto Alegre: Livraria do Advogado, 2007.

FREITAS, Juarez. A interpretação sistemática do direito. 3. ed. São Paulo: Malheiros, 2004.

GOMES, Orlando; GOTTSCHALK, Elson. Curso de direito do trabalho. 16. ed. Rio de Janeiro: Forense, 2004.

GUERREIRO, Sara. As fronteiras da tolerância - Liberdade religiosa e proselitismo na Convenção Europeia dos Direitos do Homem. Lisboa: Almedina, 2005.

HERNANDEZ, Salvatore. Uma releitura da inderrogabilidade na crise dos princípios do Direito do Trabalho. Tradução e resumo: Paulo Augusto Câmara. Revista Synthesis, n. 39, p. 43-44, 2004. 
ISRAEL, Jean-Jacques. Direito das liberdades fundamentais. Tradução: Carlos Souza. Barueri: Manole, 2005.

MACHADO, Jónatas Eduardo Mendes. Liberdade de expressão: dimensões constitucionais da esfera pública no sistema social. Coimbra: Coimbra Editora, 2002.

MACHADO, Jónatas Eduardo Mendes. Liberdade religiosa numa comunidade constitucional inclusiva: dos direitos da verdade aos direitos dos cidadãos. Boletim da Faculdade de Direito da Universidade de Coimbra, Coimbra: Coimbra Editora, 1996.

MADISON, James. The Federalist Papers No. X. The Same Subject Continued. In: HAMILTON, Alexander; MADISON, James; JAY, John. O Federalista. Campinas: Russell Editores, 2003.

QUEIROZ, Luciana Caplan de Argenton e. O meio ambiente do trabalho e os direitos da personalidade do cidadão trabalhador. In: Álvaro Sanchez Bravo (org.). Sostenibilidad Ambiental Urbana. Sevilla: ArCiBel Editores, 2012. v. 1, p. 707-728.

REIS, Raquel Tavares. Liberdade de consciencia e de religião e contrato de trabalho do trabalhador de tendência: que equilíbrio do ponto de vista das relações individuais de trabalho? Coimbra: Coimbra Editora, 2004.

RIVERO, Jean; MOUTOUCH, Hugues. Liberdades públicas. Tradução: Maria Ermantina de Almeida Prado Galvão. São Paulo: Martins Fontes, 2006.

RUARO, Regina Linden; SARLET, Ingo Wolfgang. O conteúdo essencial dos direitos fundamentais à intimidade e à vida privada na relação de emprego: o monitoramento do correio eletrônico pelo empregador. In: SARLET, Ingo Wolfgang (org.). Direitos fundamentais, informática e comunicação algumas aproximações. Porto Alegre: Livraria do Advogado, 2006. p. 227-252.

SANTOS JUNIOR, Aloisio Cristovam dos. Liberdade religiosa e contrato de trabalho: a dogmática dos direitos fundamentais e a construção de respostas constitucionalmente adequadas aos conflitos religiosos no ambiente de trabalho. Niterói, RJ: Impetus, 2013.

SAVATIER, Jean. La libertè dans le travail. Droit Social, n. 1, p. 49-58, Janvier 1990.

SETUBAL, Alexandre Montanha de Castro. Aspectos interdisciplinares e jurídico-trabalhistas do direito fundamental à liberdade religiosa. Dissertação (Mestrado em Direito) - Programa de Pós-Graduação em Direito, Faculdade de Direito, Universidade Federal da Bahia, Salvador, 2011.

SILVA, José Afonso da. Curso de direito constitucional positivo. 24. ed. rev. e atual. São Paulo: Malheiros, 2005.

SILVA NETO, Manoel Jorge e. Proteção constitucional à liberdade religiosa. Rio de Janeiro: Lumen Juris, 2008.

WANDELLI, Leonardo Vieira. Despedida abusiva: o direito (do trabalho) em busca de uma nova racionalidade. São Paulo: LTr, 2004.

WAQUET, Philippe. L'entreprise et les libertés du salarié: du salarié-citoyen au citoyen-salarié. Paris: Liaisons, 2003. 
